\title{
MEGALOBLASTIC ANAEMIAS OF GASTROINTESTINAL ORIGIN
}

\author{
J. P. KNowles, M.A., M.B., M.R.C.P. \\ M.R.C. Research Fellow \\ T. A. J. PRANKerd, M.D., M.R.C.P. \\ Medical Unit, University College Hospital Medical School, London, W.C.I
}

THERE exist two known anti-megaloblastic substances, vitamin $\mathrm{B}_{12}$ and folic acid. Both of these are absorbed from the small intestine and the body is dependent on their dietary supply to prevent abnormal changes in hæmopoiesis. Deficiencies of these compounds may arise in a number of ways, but one important group arises from abnormalities of the small intestine interfering with normal absorptive mechanisms.

\section{Absorption}

The efficient absorption of vitamin $B_{12}$ is known to depend on the formation of a complex with an unspecified material, intrinsic factor. The mechanism through which absorption is actually promoted and the problem whether intrinsic factor is simultaneously absorbed or left in the small bowel remain obscure, but the site of absorption is well delineated and appears to be in the terminal ileum (McIntyre, Sachs, Krevans and Conley, 1956; Cox, Meynell, Cooke and Gaddie, 1958; Booth and Mollin, 1959). Thus loss of intrinsic factor, as in pernicious anæmia, after total gastrectomy and sometimes after partial gastrectomy (Badenoch, Evans, Richards and Witts, 1955; Maclean, 1957) or loss of the terminal ileum, either by surgical resection or disease, inevitably leads to malabsorption of vitamin $B_{12}$.

It appears that calcium ions may be necessary for efficient absorption of the vitamin $B_{12}$-intrinsic factor complex (Gräsbeck, Kantero and Siurala, 1959) and it is possible that the removal of calcium ions by fatty acids may partly impair vitamin $B_{12}$ absorption in steatorrhœa, but little is known yet about their role. If calcium ions were an important factor, then malabsorption of vitamin $B_{12}$ in pancreatic steatorrhoea would be expected to occur, and this has been shown (Halstead, Lewis, Hvolbolt, Gasseter and Swenseid, 1956; Frost, Goldwein and Kaufman, 1957; McIntyre and others, 1956). However, megaloblastic anæmia has never been described secondary to pancreatic disease (Mollin, 1959).

Even less is known about the absorption of folic acid. In the diet much of the folic acid exists in conjugated form, and this has been shown to be less well absorbed than the unconjugated form (Jandl and Lear, 1956). Whether this difference is due to preferential absorption of the unconjugated form or difficulty in deconjugating, or both, is unknown, as is the part played by digestive enzymes.

The site of absorption of folic acid is also not known with certainty. From a study of patients with Crohn's disease affecting various parts of the small intestine Cox and others (1958) and Doig? and Girdwood (1960) found malabsorption of folic acid was most frequent when the disease affected the jejunum. Resection of sufficient ileum to result in malabsorption of vitamin $\mathrm{B}_{12}$ does not as a rule lead to malabsorption of folic acid (Chanarin, Anderson and Mollin, 1958a; Cox and others, 1958; Doig and Girdwood, 1960). However, there is no conclusive evidence that the absorption of folic acid is confined to the proximal small intestine.

The bacterial flora of the gut play a rather mysterious role in the absorption of vitamin $B_{12}$ and folic acid. A normal flora which is probably confined only to the terminal part of the ileum is not likely to influence normal absorption, but in many diseases of the small intestine bacteria may flourish where they do not normally exist. Since some bacteria show an avid utilization of vitamin $B_{12}$ (Burkholder, 1952; Doig and Girdwood, 1960), it is possible that a profuse growth would compete with the body for the available vitamin leading to a deficiency. Certainly the response of some of the disorders to be considered to broadspectrum antibiotics lends support to such a theory. Most bacteria actually synthesize vitamin $B_{12}$ and folic acid, but since these organisms are mainly confined to the large bowel, their synthetic 
products are not available for absorption. This topic has been well reviewed by French (1961).

\section{Results of Malabsorption}

Malabsorption of vitamin $B_{12}$ and folic acid inevitably leads to depletion of the body stores of these vitamins. The sequence of changes in the development of vitamin $B_{12}$ deficiency is better known than in that of folic acid, because pure vitamin $\mathrm{B}_{12}$ deficiency occurs after total gastrectomy and in pernicious anæmia. The speed of onset of symptoms and signs will obviously depend on the size of the body store when absorption begins to fail. For some reason the sequence of changes is quicker in pernicious anæmia in relapse than after total gastrectomy and Mollin (1959) suggests that this may be due to the fact that patients with pernicious anæmia are not infrequently incompletely repleted with vitamin $B_{12}$. Paulson.and Harvey (1954) followed up 80 patients after total gastrectomy. Six of them survived long enough to develop megaloblastic anæmia two to seven years (average 4.25 years) after the operation.

It can be estimated that the body stores of vitamin $B_{12}$ amount to about $I \mathrm{mg}$., which on values for daily requirement of about I to $2 \mu \mathrm{g}$ would account for the latent interval of about two to three years before the onset of anæmia.

In course of time vitamin $B_{12}$ deficiency leads to megaloblastic anæmia often associated with leucopœnia and even thrombocytopœnia. Subacute combined degeneration may complicate this deficiency regardless of its cause.

Pure dietary folic acid deficiency in adults was reported for the first time (Knowles, Prankerd and Westall, 196I) in patients fed, perforce, on artificial diets. The stores of folic acid became sufficiently depleted to give abnormal histidine tests after four to six weeks. At this time there were no hæmatological or bone marrow changes. After 10 months one of the patients was still not anæmic $(\mathrm{Hb} .=15 \mathrm{~g} / / \mathrm{r} 00 \mathrm{ml}$.). These observations are in keeping with those of Najjar and Holt (1943) and Najjar and Barrett (1945), who fed human volunteers on diets containing 13 to $17 \mu \mathrm{g}$. per day of folic acid. After 18 months there were no hæmatological abnormalities. Stores of ' folic acidlike' substances have been estimated at about 5 to $10 \mathrm{mg}$. (Girdwood, 1959) with a daily requirement of 5 to $10 \mu \mathrm{g}$. (Knowles and others, I96r). Folic acid deficiency eventually leads to identical hæmatological changes as vitamin $B_{12}$ deficiency, but neurological sequelæ do not occur.

The role of vitamin $B_{12}$ and folic acid deficiency in preserving the integrity of the mucous membranes of the gastrointestinal tract is much debated. Evidence is accumulating that deficiency of either may lead to malabsorption (Lambert, Prankerdœ and Smellie, r96r).

\section{Detection of Deficiency and Measurement of Absorption}

The measurement of absorption of vitamin $\mathrm{B}_{12} \stackrel{\text { 음 }}{\rightarrow}$ and folic acid can only be done effectively by the use of radioactive isotopes incorporated into the $\frac{\bar{\sigma}}{\overline{0}}$. vitamin. With such material physiological quanti- $\overrightarrow{\mathbb{D}}$ ties of these substances can be incorporated into $\frac{\Omega}{0}$ the diet. Measurements of absorption after giving $\infty$ loading doses impose abnormal concentration- $\overrightarrow{0}$ gradients throughout the absorbing surface of the $\overrightarrow{-}$ small intestine and cannot be regarded as sensitive $\vec{\sigma}$ tests for defective absorption, though they are $\frac{D}{0}$ undoubtedly a guide to intestinal function.

Radioactive vitamin $B_{12}$ and folic acid are now $\stackrel{3}{\omega}$. easily obtainable. The former, labelled with ${ }^{58} \mathrm{Co}, \stackrel{\sim}{ }$ can be estimated by readily available apparatus. Folic acid labelled with tritium requires a liquid $\stackrel{+}{\ddagger}$ scintillation counter (Anderson, Belcher, Chanarin जิ and Mollin, 1960).

It should be borne in mind that the demonstration of impaired absorption does not necessarily imply a body deficiency of that compound. For $\mathbb{\varnothing}$ this assessment other tests are available. In the $\frac{\Phi}{3}$ case of vitamin $B_{12}$, estimation of the serum level $\underset{\mathbb{D}}{\mathscr{D}}$ is a reliable means of assessment of body stores (Spray and Witts, 1958), but in the case of fole acid serum measurements have not yet proved. wholly successful (Herbert, Wasserman, Franl Pasher and Baker, I959; Baker, Herbert, Frank, Pasher, Hutner, Wasserman and Sobotka, I959; Baker, Herbert, Frank, Pasher, Sobotka and Wasserman, I960; Niewig, Faber, de Vries, Stenfert Kroese, 1954); and as a result various indirect procedures have been introduced to assess body stores of folic acid. The urinary excretion of folic acid after a test dose might be expected to be proportional to the degree of tissue saturation, but, whilst this is roughly true, there is sufficient overlap between normals and abnormals to make the test unsatisfactory (Cox, Meynell and Cooke, 196r). Chanarin, Anderson and Mollin (1958b) showed that the rate of clearance from the plasma of an intravenous dose of folic acid was proportional to the degree of folic acid deficiency, but it also seems to be proportional to the degree of marrow activity and therefore not specific; the results of this test before and after treatment with small doses of folic acid which have not been reported would be of interest.

Bakerman, Silverman and Daft (195I) noted a glutamic acid precursor in the urine of folic aciddeficient rats which was later shown to be formi- $\frac{\mathscr{D}}{\mathscr{D}}$ minoglutamic acid (FIGLU) (Borek and Waelsch, $\stackrel{\oplus}{?}$ 1953; Seegmiller, Silverman, Tabor and Mehler, 1954). FIGLU is an intermediate in histidine 
metabolism and by giving a suitable dose of histidine it has been shown that the excretion of FIGLU can be increased (Tabor, Silverman, Mehler, Daft and Bauer, 1953), thus providing a suitable laboratory test for folic acid deficiency (Luhby, Cooperman and Teller, 1959a and b; Knowles, Prankerd and Westall, 1960).

Using this test we have found the following results in 105 cases of steatorrhœa:

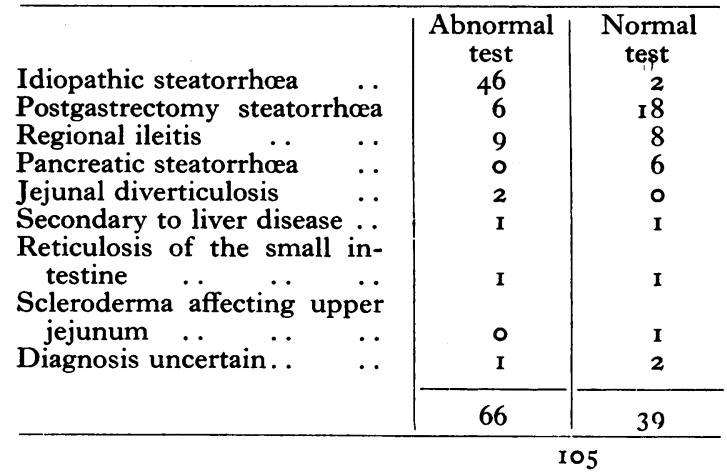

\section{Diseases of the Small Intestine}

\section{Idiopathic Steatorrhoea, Coeliac Disease}

Idiopathic steatorrhœa probably comprises a group of diseases for which there is no satisfactory name. Many alternatives (adult cœliac disease, gluten-induced enteropathy, primary malabsorption syndrome) have been suggested, but none has met with universal approval. Gluten-sensitivity seems to be a common cause in adults and even more so in children.

Megaloblastic anæmia is much less common in children than in adults. Sheldon (1958) gives an incidence of $9 \%$. It is known to be much commoner in adults, but exact figures are scarce. Cooke, Peeney and Hawkins (1953) found macrocytic anæmia in two-thirds of Ioo patients; 49 of the 100 had bone marrow examinations and 17 had definite megaloblastic changes, in were entirely normal and the other 21 were intermediate.

The anæmia may be due to deficiency of iron, folic acid or vitamin $B_{12}$. A dimorphic blood picture with evidence of macrocytosis and hypochromia is very suggestive of malabsorption.

Serum vitamin $B_{12}$ levels are low and absorption of labelled vitamin $\mathrm{B}_{12}$ is reduced below normal in approximately half the patients which have been studied, though figures vary from one group of worker to another (Mollin, Booth and Baker, I957; Spray and Witts, 1958; Meynell, Cooke, Cox and Gaddie, I957; Halstead, Lewis and Gasseter, 1956; Frost and others, 1957; Oxenhorn, Estren, Wasserman and Aldersberg, I958; Turnbull, 1954; Callender and Evans, 1955; Doig and Girdwood, 1960).
Absorption of folic acid has been reported to be reduced in over $90 \%$ of patients (Chanarin and others, 1958a; Cox and others, 1958; Doig and Girdwood, 1960). In all these studies large doses of folic acid were used ( 3 to $5 \mathrm{mg}$.), doses which are I 5 to 25 times greater than the total average daily intake; it may well be that these tests are really measuring the absorptive capacity of the gut rather than the physiological absorption of folic acid. Such tests are, however, useful measures of intestinal function. Anderson and others (1960) used more physiological doses of labelled folic acid and found malabsorption in nine out of 13 patients as measured by fæcal excretion.

Folic acid deficiency, when assessed by the excretion of an excess of FIGLU after a histidine load, appears to be at least as common as malabsorption when measured by the folic acid load tests (Knowles, I96I).

\section{Tropical Sprue}

This is a most interesting condition with many unexplained features. The geographical distribution of tropical sprue suggests that it may be related to dietary habits. Thus it is common in Cuba and Puerto Rica, but rare in neighbouring Jamaica. It occurs in Hong Kong, but is uncommon in Singapore. It is common in India, but almost absent from Africa and the Pacific (Gardner, 1958). French (1955, I96I) has suggested that this may be related to the consumption of unsaturated fatty acids in the sprue areas. Tropical sprue can occur within a few weeks of arrival in an endemic area and in patients in an apparently excellent state of nutrition, suggesting, in the early stages at least, that malnutrition is not an important factor. Jejunal biopsy changes have been noted within Io days of the onset of diarrhœa (Butterworth, C. E., personal communication to Gardner, 1958).

Treatment of the established disease may be affected by removal from the affected area, by folic acid or by antibiotics. The prognosis is usually excellent, but an occasional case reaches an apparently irreversible stage. Folic acid deficiency has not been clearly demonstrated, but most cases respond to folic acid alone, suggesting that deficiency of this vitamin, however determined, is important in keeping the disease active. Not all such patients are anæmic. There is often no evidence of vitamin $B_{12}$ deficiency in the early stages of the disease (Frazer, 1960; Gardner, 1958), but it is not uncommon in the later stages (Gardner, 1958).

In a proportion of patients it is necessary to give antibiotics before a full remission is obtained (French, 196r; French, Gaddie and Smith, 1956). Antibiotics alone may also induce a remission 
(Keele and Bound, 1946; Foy and Kordi, 1954).

The incidence of megaloblastic anæmia varies in reports from different parts of the world, but it would seem to be inevitable if the disease is not treated or it does not undergo spontaneous remission.

\section{Pancreatic Steatorrhoea}

As previously mentioned, megaloblastic anæmia has not been recorded in this type of steatorrhœa, although absorption of vitamin $\mathrm{B}_{12}$ is impaired.

Absorption of folic acid is normal (Cox and others, 1958) and there does not appear to be a deficiency in the body stores of folic acid (Knowles, I96I).

\section{Cirrhosis of the Liver and Megaloblastic Ancemia}

Although steatorrhœa may occur as a complication of cirrhosis of the liver, megaloblastic anæmia, when it occurs, is probably not due to this cause. Nutritional deficiency or hepatic failure would seem the most likely causes. In any case, it is rare.

\section{Intestinal Strictures, Resections, Fistula, Blind Loops and Yejunal Diverticula}

Two mechanisms operate in the production of megaloblastic anæmia. First, the terminal ileum (the site of vitamin $\mathrm{B}_{12}$ absorption) may be bypassed by fistulæ or removed by resection. Secondly, strictures or jejunal diverticulæ may give rise to blind loops of intestine. Here microorganisms not normally found in the small intestine multiply and interfere with absorption. One of the ways they may do this is by actually competing with the intestine for vitamin $B_{12}$ (Doig and Girdwood, I960; Badenoch, Bedford and Evans, 1955). Organisms have not been shown to compete for folic acid in vitro. Nevertheless, folic acid deficiency does occasionally arise, though it is much less common than vitamin $B_{12}$ deficiency. Girdwood (1960) reports a possible case and we have seen two cases where there was an abnormal excretion of FIGLU. One of these patients also had a low vitamin $B_{12}$ level (80 $\mu \mu \mathrm{g} . / \mathrm{ml}$.) and polycythæmia vera, but the other patient had no other cause for her megaloblastic anæmia. Girdwood (I960) suggests that folic acid deficiency may arise from direct bacterial irritation of the gut wall. Folic acid absorption tests using high dosage of folic acid are usually normal in these patients (Doig and Girdwood, 1960). Impaired absorption of vitamin $B_{12}$ has been demonstrated by Halstead, Lewis, Hvolbolt, Gasseter and Swendseid (1956), Frost and others (1957), Mollin and others (1957) and Oxenhorn and others (1958), and low serum $B_{12}$ levels by Spray and Witts (1958). Megaloblastic anæmia after partial gastrectomy is usually due to subsequent atrophy of the stomach remnant, but occasionally a bling loop is the cause (Naish and Capper, 1953).

\section{Infiltrative Diseases of the Small Intestine}

In regional ileitis and jejunitis megaloblastic anæmia is occasionally observed. The mechanis operates through the formation of blind loops fistulæ, or the wall of the small intestine may be diseased that absorption is impeded. In the first group cure may sometimes be effected by ans biotics and in the latter group corticosteroids will occasionally bring amelioration (Cooke, 1958).

Tuberculosis (Davidson, 1950) and reticulos葹 (Girdwood, 1960) of the small intestine are rage causes of megaloblastic anæmia.

Amyloidosis of the small intestine and Whipple disease not infrequently lead to steatorrhœa, but so far as we are aware, megaloblastic anæmia his not been reported. Hendrix, Black-Schaffeł, Withers and Handler (1950), in a general review, state that macrocytic anæmia is uncommon fif Whipple's disease and report one of their four cases as having a bone marrow showing 'slight arrest of erythro- and myelo-blastic tissues '. 요

\section{Fish Tape Worm}

Diphyllobothrium latum, the fish tape worm, which affects particularly the population of Bits land and Japan, has been directly demonstrated to have a high affinity for vitamin $\mathrm{B}_{12}$. In vi if competes with intrinsic factor for the vitamin, $b$ ot if intrinsic factor and vitamin $B_{12}$ are mixed prio to ingestion there is no interference with absor tion (Brante and Ernberg, 1958). Infestation wifh this worm is common in Finland (9 to $12 \%$ of the population, depending on the area) (von Bons dorff, 1948), though only a small percentage off infected persons develop significant anæmia ( $\mathrm{I}$ 퐁 I 13, I in 659) (Tötterman, I944).

\section{Diagnosis}

The peripheral blood pictures in all cases megaloblastic anæmia are often indistinguishabli, showing macrocytosis and considerable deformig of the red cells. All cases of vitamin $B_{12}$ deficiency can show subacute combined degeneration of the cord. A most important clue to the occurrence malabsorption in the ætiology is the presence of coincidental evidence of iron deficiency. This absent in untreated pernicious anæmia and the rarer causes of megaloblastosis; it manifests itser in the peripheral blood by the appearance of hyp $8=$ chromic red cells. Other evidence of iron de ficiency may be obtained from serum iron levelis.

Achlorhydria as demonstrated by the augmented histamine test seems synonymous with total gastrifg atrophy, and if pernicious anæmia is not prese it may be expected to develop (Card and Circus, 
1958). However, the presence of free acid excludes pernicious anæmia except in young people (Lambert and others, 1961). Evidence of coincident folic acid deficiency is also present in the more severe cases of pernicious anæmia (Knowles and Prankerd, r96r).

Ultimate diagnosis therefore rests on a combination of the histological and radiological demonstration of an abnormality in the gastrointestinal tract, together with evidence of malabsorption. Barium studies showing flocculation patterns are important, as is the demonstration of malabsorption by estimation of daily fat and urinary calcium excretion. The latter may rarely be abnormal in pernicious anæmia (Lambert and others, 196r). Final differentiation from pernicious anæmia may be achieved by studies with ${ }^{58} \mathrm{Co}$-labelled vitamin $B_{12}$ in which the restoration of normal absorption is demonstrated by administering vitamin $B_{12}$ with intrinsic factor. The amount of the latter used is important, since excessive amounts may increase vitamin $\mathrm{B}_{\mathbf{1 2}}$ absorption in idiopathic steatorrhœa (Callender and Evans, I955).

Finally, mucosal biopsy from the jejunum and stomach is particularly useful in diagnosis as specific changes can often be detected in different disorders. Pernicious anæmia patients show complete gastric atrophy. Characteristic changes are found in the small intestine in idiopathic steatorrhœa, tropical sprue, regional ileitis and Whipple's disease. The finding of a normal, or nearly normal, intestinal biopsy is usual in post-gastrectomy steatorrhœa, pancreatic steatorrhœa, cirrhosis and in steatorrhœea associated with blind loops and jejunal diverticulosis.

\section{Treatment}

Symptomatic treatment of megaloblastic anæmia of any cause may be effected by giving folic acid or vitamin $B_{12}$, depending on the deficiency.

When megaloblastic anæmia is due to intestinal causes more specific therapy is usually desirable, directed at the cause. Thus nearly all children with coliac disease and most adults with idiopathic steatorrhœa will respond to withdrawal of gluten from the diet. The excretion of FIGLU will cease in two to four months after starting on a gluten-free diet, suggesting complete replacement of the body stores of folic acid after this time (Knowles, 196I).

The treatment of tropical sprue has already been discussed.

Antibiotics will usually induce a hæmatological remission in the blind-loop syndrome, but it is interesting to note that neomycin, the most powerful intestinal antibiotic of all, does not do this (Halstead, Lewis and Gasseter, 1956). Neomycin is not absorbed, so possibly does not reach the blind loops in sufficient concentration to be effective. Surgical procedures will be required when correction of some anatomical defect is necessary.

\section{REFERENCES}

Anderson, B., Belcher, E. H., Chanarin, I., and Mollin, D. L. (ig6o): The Urinary and Fæcal Excretion of Radioactivity After Oral Doses of ${ }^{3} \mathrm{H}$ Folic Acid, Brit. F. Hamat., 6, 439.

Badenoch, J., Bedford, P. D., and Evans, J. R. (1955): Massive Diverticulosis of the Small Intestine with Steatorrhœa and Megaloblastic Anæmia, Quart. Y. Med., 24, 321.

-, Evans, J. R., Richards, W. C. D., and WitTs, L. J. (I955): Megaloblastic Anæmia following Partial Gastrectomy and Gastroenterostomy, Brit. F. Hamat., r, 339.

Baker, H., Herbert, V., Frank, O., Pasher, I., Hutner, S. H., Wasserman, L. R., and Sobotka, H. (i959): A Microbiologic Method for Detecting Folic Acid Deficiency in Man, Clin. Chem., 5, 275. ,,--1, Sobotka, H., and Wasserman, L. R. (1960): The Measurement of Folic Acid Activity in Serum. A Diagnostic Aid in the Differentiation of the Megaloblastic Anæmias, Blood, r5, 228.

Bakerman, H., Silverman, M., and DafT, F. S. (1951): Influences of Succinyl Sulfathiazolé and Folic Acid on Glutamic Acid Excretion, F. biol. Chem., r88, i 17.

Booth, C. C., and Mollin, D. L. (1959): The Site of Absorption of Vitamin B $_{12}$ in Man, Lancet, $\mathbf{i}, \mathbf{1} 8$.

Borek, B. A., and Waelsch, H. (1953): The Enzymatic Degradation of Histidine, f. biol. Chem., $205,459$.

Brante, G., and ERnberg, T. (1958): The Mechanism of Pernicious Tape Worm Anæmia Studied with ${ }^{60}$ Cobaltlabelled Vitamin $\mathrm{B}_{12}$, Acta med. scand., 160, $9 \mathrm{I}$.

Burkholder, P. R. (1952): Microbiological Studies in Materials which Potentiate Oral Vitamin $B_{12}$ Therapy in Addisonian Anæmia, Arch. Biochem., 39, 322.

Callender, S. T., and Evans, J. R. (1955): Observations on the Relationship of Intrinsic Factor to the Absorption of Labelled Vitamin $\mathrm{B}_{12}$ from the Intestine, Clin. Sci., 4, 387.

CARD, W. I., and Circus, W. (1958): Anacidity, in 'Modern Trends in Gastro-enterology', chap. I I, p. 177. Ed. Avery Jones, F. London: Butterworth.

Chanarin, I., Anderson, B. B., and Mollin, D. L. (1958a): The Absorption of Folic Acid, Brit. F. Hamat., 4, r 56.

$-,-1$ ( $1958 \mathrm{~b})$ : The Clearance from the Plasma of Folic Acid Intravenously in Normal Subjects and Patients with Pernicious Anæmia, Ibid., 4, 435.

Cooke, W. T. (1958): Anæmia and the Alimentary Tract, Lancet, ii, 258.

-, Peeney, A. L. P., and Hawkins, C. F. (1953): Symptoms, Signs and Diagnostic Features of Idiopathic Steatorrhœa, Quart. F. Med., 22, 59.

Cox, E. V., Meynell, M. J., and Cooke, W. T. (r96r): Folic Acid Deficiency, Postgrad. med. F., 37, 252.

$\longrightarrow,-,-$ and GadpIE, R. (1958): The Folic Acid Excretion Test in the Steatorrhœa Syndrome, Gastroenterology, $35,390$. 
Davidson, L. S. P. (i953): Megaloblastic Anæmia and Subacute Combined Degeneration from Tuberculous Disease of the Small Intestine, Gastroenterologia (Basel), 79, 342.

Doig, A., and GirDwood, R. H. (1960): The Absorption of Labelled Cyanocobalamin and Folic Acid in Intestina Malabsorption, Quart. F. Med., 29, 333.

Foy, H., and KoRDI, H. (1954): The Hæmaturic Action of Penicillin in Megaloblastic Anæmia and its Relationship to Vitamin $\mathrm{B}_{12}$ Metabolism and the Intestinal Flora, Trans. roy. Soc. trop. Med. Hyg., 48, 17.

Frazer, A. C. (1960): Pathogenetic Concepts of the Malabsorption Syndrome, Gastroenterology, 38, 389 .

FRENCH, J. M. (1955): The Ætiology and Mechanism of Steatorrhœea, Postgrad. med. F., 3r, 299.

(I96I): Problems Raised by the Treatment of Steatorrhœa with Anti-bacterial Drugs, Ibid., 37, 259.

-, Gaddie, R., and Smith, N. M. (1956): Tropical Sprue, Quart. F. Med., 25, 333.

Frost, J. W. Goldwein, M. I., and KAUfman, B. D. (1957): Studies of $\mathrm{B}_{12} \mathrm{Co}^{60}$ Absorption in Malabsorption Syn® drome: Results Before and During Specific Therapy, Ann. intern. Med., 47, 293.

GARDNER, F. H. (1958): Tropical Sprue, New Engl. Y. Med., 258, 791 and 835.

GirDwood, R. H. (I959): The Role of Folic Acid in the Blood Disorders, Brit. med. Bull., I5, I3. (1960): Folic Acid, its Analogs and Antagonists, in 'Advances in Clinical Chemistry', 3, 235. New York Academic Press Inc.

Gräbeck, R., Kantero, I., and Sivrala, M. (I959): Influence of Calcium Ions on Vitamin $B_{12}$ Absorption i Steatorrhœa and Pernicious Anæmia, Lancet, $\mathbf{i}, 234$.

Halstead, J. A., Lewis, P. M., Hvolbolt, E. E., Gasseter, M., and Swendseid, M. E. (1956): An Evaluation of the Fæcal Recovery Method for Determining Intestinal Absorption of Cobalt ${ }^{60}$-labelled Vitamin $\mathrm{B}_{12}$, F. Lab. clin ${ }_{\text {Med., }} \mathbf{4 8}, 92$.
. , a and GASSETrR, M. (1956): Absorption of Vitamin $\mathrm{B}_{12}$ in the Syndrome of Megaloblastic Anæmia Associated
with Intestinal Stricture or Anastomosis, Amer. F. Med., 20, 42 .

Hendrix, J. P., BlaCk-Schaffer, B., Withers, R. W., and HandLer, P. (1950): Whipple's Intestinal Lipodystrophy

Report of four cases and discussion of possible pathogenic factors, A.M.A. Arch. intern. Med., 85, $9 \mathrm{I}$.
Herbert, V., Wasserman, L. R., Frank, O., Pasher, I., and Baker, H. (I959): Value of Fasting Serum 'Folic Acid Levels, Fed. Proc., 18, 970.

JandL, J. H., and Lear, A. A. (1956): The Metabolism of Folic Acid in Cirrhosis, Ann. intern. Med., 45, 1027.

KEELE, J., and Bound, J. P. (1946): Sprue in India: A Clinical Survey of 600 Cases, Brit. med. $\mathcal{F} .$, i, 77.

KNow LES, J. P. (1961): Excretion of Formiminoglutamic Acid in Steatorrhœa, Gut (in press).

—, and PRANKERD, T. A. J. (I 961): Abnormal Folic Acid Metabolism in Pernicious Anæmia, Clin. Sci. (in press).

- - - and Westall, R. G. (1961): Folic Acid Requirements in Man, F. Physiol., 157, 24P. Deficiency, Lancet, ii, 347 .

Lambert, H. P., Prankerd, T. A. J., and Smellie, J. M. (I96I): Pernicious Anæmia in Childhood, Quart. F. M.g్g. 30, 7 I.

Luhby, A. L., Cooperman, J. M., and Teller, D. N. (1959a): The Urinary Excretion of Formiminoglutamic Actat Application in Diagnosis of Folic Acid Deficiency, Amer. F. clin. Nutr., 7, 397.

-,-1 - ( $1959 \mathrm{~b})$ : Histidine Metabolic Loading Test to Distinguish Folic Acid Deficiency from Vitamin $\mathbf{B}_{1}$

Deficiency in Megaloblastic Anæmias, Proc. Soc. exp. Biol. (N.Y.), Ior, 350 .
McInTyre, P., Sachs, M. V., Krevans, J. R., and Conley, C. L. (1956): Pathogenesis and Treatment of Macrocyti

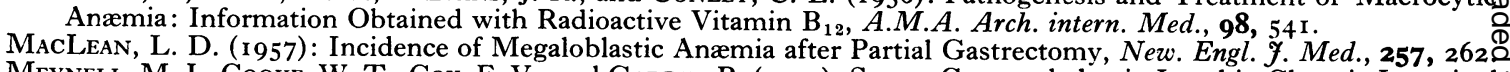

Meynell, M. J., Cooke, W. T., Cox, E. V., and GADDIE, R. (1957): Serum Cyanocobalamin Level in Chronic Intestinat Disorder, Lancet, i, $90 \mathrm{I}$.

Mollin, D. L. (1959): Radioactive Vitamin $\mathrm{B}_{12}$ in the Study of Blood Diseases, Brit. med. Bull., 15, 8.

-, Booth, C. C., and BAKER, S. J. (1957): The Absorption of Vitamin B in Control Subjects in Addisonian Per nicious Anæmia and in the Malabsorption Syndrome, Brit. F. Hamat., 3, 412.

NAISH, J., and CAPPER, N. M. (1953): Intestinal Cul-de-sac Phenomena in Man, Lancet, ii, 597.

NAJJAR, V. A., and BARRETT, R. (1945): The Synthesis of B Vitamins by Intestinal Bacteria, Vitamins \& Hormones, 3, 23 을

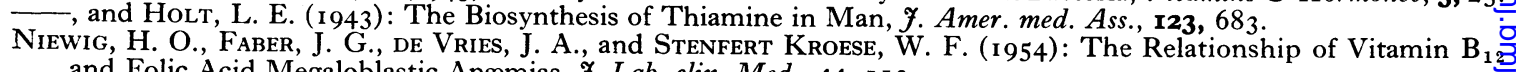
and Folic Acid Megaloblastic Anæmias, F. Lab. clin. Med., 44, I 13.

Oxenhorn, S., Estren, S., Wasserman, L. R., and Aldersberg, D. (1958): Malabsorption Syndrome: Intestinab Absorption of Vitamin $\mathrm{B}_{12}$, Ann. intern. Med., 48, 30 .

Paulson, M., and Harvey, J. C. (I954): Hæmatological Alterations after Total Gastrectomy, F. Amer. med. Ass. 0 156, 1556 .

Seegmiller, J. E., Silverman, M., Tabor, H., and Mehler, A. (1954): Synthesis of a Metabolic Product of Histidine $?$ F. Amer. chem. Soc., 76, 6205 .

Sheldon, W. P. H. (1958): Anæmia of the Alimentary Tract, Lancet, ii, 258.

Spray, G. H., and WITTS, L. J. (1958): Results of Three Years' Experience with Microbiological Assay of Vitamin $B_{1} \stackrel{乛}{\Omega}$ in Serum, Brit. med. $\mathcal{F} ., \mathbf{i}, 295$.

Tabor, H., Silverman, M., Mehler, A. H., Daft, F. S., and Bauer, H. (1953): 1- Histidine Conversion to a Urinary Glutamic Acid Derivative in Folic Acid Deficient Rats, F. Amer. chem. Soc., 75, 756.

Tötrerman, G. (1944): On the Occurrence of Pernicious Tape-worm Anæmia in the Carriers of Diphyllobothriump Latum, Acta med. scand., 118, 410.

Turnsull, A. (1954): Experiences with Labelled Vitamin B ${ }_{12}$, Proc. roy. Soc. Med., 47, 30.

VON BONSDORFF, B. (1948): Pernicious Anæmia Caused by Diphyllobothrium Latum in the Light of Present Investiga tions, Blood, 3, 9I. 